\title{
HUBUNGAN TINGKAT PENGETAHUAN PEMELIHARAAN KESEHATAN GIGI DAN TINGKAT KEPARAHAN KARIES GIGI SISWA SDN TUMALUNTUNG MINAHASA UTARA
}

\author{
${ }^{1}$ Jacky Ch. Lintang \\ ${ }^{2}$ Henry Palandeng \\ ${ }^{2}$ Michael A. Leman \\ ${ }^{1}$ Kandidat Skripsi Program Studi Pendidikan Dokter Gigi Fakultas Kedokteran \\ ${ }^{2}$ Bagian Ilmu Kesehatan Masyarakat Fakultas Kedokteran \\ ${ }^{2}$ Program Studi Pendidikan Dokter Gigi Fakultas Kedokteran \\ Universitas Sam Ratulangi Manado \\ Email: Jackie_lintang@gmail.com
}

\begin{abstract}
The disease of teeth and mouth that most suffered by Indonesian society is caries. Caries is disease in hard tissue of teeth that occurred beginning with process of demineralization of dental hard tissue, followed by tooth decay organic matter. The Indonesian population prevalence of caries is $53.2 \%$. School period is most susceptible to dental caries. Children who have a good knowledge in general, has good behavior to maintain their oral health. The purpose of this study was to examine the relationship knowledge of dental health maintenance and severity of dental health. This type of research is a descriptive study with cross sectional design. The population of this study is all children in $5^{\text {th }}$ grade of Tumaluntung Primary School in North Minahasa, with total sample 45 students. Data collection is done by filling out questionnaire and examination of dental caries index. The results showed that there was no strong relationship between the level of knowledge of dental health maintenance with severity of dental caries ( $\mathrm{r}=0.372$ ).
\end{abstract}

Keywords: knowledge; dental health maintenance; dental caries severity

\begin{abstract}
Abstrak: Penyakit gigi dan mulut yang paling banyak diderita masyarakat Indonesia adalah karies. Karies merupakan suatu penyakit pada jaringan keras gigi yang terjadi diawali dengan proses demineralisasi jaringan keras gigi diikuti dengan kerusakan bahan organik gigi. Di Indonesia prevalensi penduduk yang mengalami karies sebanyak 53,2\%. Masa sekolah merupakan waktu yang paling rentan terhadap kemungkinan terjadinya karies. Anak-anak yang memiliki pengetahuan baik pada umumnya memiliki perilaku yang baik untuk mejaga kesehatan gigi dan mulut mereka.Tujuan penelitian ini yaitu untuk melihat hubungan pengetahuan pemeliharaan kesehatan gigi dengan tingkat keparahan karies gigi. Jenis penelitian ini adalah penelitian deskriptif dengan desain cross sectional. Populasi penelitian ini adalah seluruh anak kelas V SDN Tumaluntung Minahasa Utara, dengan jumlah sampel sebanyak 45 siswa. Pengambilan data dilakukan dengan pengisian kuesioner dan pemeriksaan indeks karies.Hasil penelitian menunjukkan bahwa tidak ada hubungan yang kuat antara tingkat pengetahuan pemeliharaan kesehatan gigi dengan tingkat keparahan karies gigi $(\mathrm{r}=0,372)$.
\end{abstract}

Kata kunci: pengetahuan; pemeliharaan kesehatan gigi; keparahan karies gigi

Penyakit gigi dan mulut yang paling banyak diderita masyarakat Indonesia adalah karies gigi, yaitu sekitar $90 \%{ }^{1}$
Berdasarkan data Riset Kesehatan Dasar (RISKESDAS) tahun 2013 dari Departemen Kesehatan, prevalensi 
penduduk Indonesia yang mengalami peningkatan jumlah karies gigi sebanyak 53,2\% dibandingkan tahun 2007 yang berjumlah 43,4\%. ${ }^{2}$ Masa anak-anak khususnya usia sekolah dasar, merupakan waktu paling rentan terhadap kemungkinan terjadinya karies gigi, sehingga perlu diberikan pengetahuan tentang pentingnya menjaga kesehatan gigi, pengobatan, dan cara pencegahan. Berdasarkan data RISKESDAS tahun 2013, tingginya prevalensi anak di bawah usia 12 tahun (42,6\%) yang mengalami peningkatan sebesar 13,7\% dibandingkan tahun 2007 (28,9\%) membuktikan tidak terawatnya kondisi gigi anak usia sekolah di Indonesia. ${ }^{3}$ Tingkat prevalensi karies tinggi yang tinggi tersebut mungkin mencerminkan tingkat pengetahuan tentang kesehatan gigi yang rendah.

SDN Tumaluntung Minahasa Utara merupakan salah satu sekolah dasar yang cukup besar, memiliki standarisasi nasional dalam bidang akademik, dan sarana UKGS yang menunjang pemeliharaan kesehatan gigi di sekolah. Namun, terdapat banyak laporan bahwa murid di sekolah ini sebagian besar tidak masuk sekolah karena menderita sakit gigi (survei awal 5 April 2014), sehingga merupakan hambatan yang cukup mengganggu proses belajar mengajar. Oleh karena itu, peneliti tertarik untuk melakukan penelitian mengenai hubungan tingkat pengetahuan pemeliharaan kesehatan gigi dengan tingkat keparahan karies gigi pada siswa SDN Tumaluntung Minahasa Utara.

\section{TINJAUAN TEORITIS}

Pengetahuan adalah hasil dari tahu dan ini terjadi setelah orang melakukan penginderaan terhadap suatu objek tertentu. Pengetahuan dapat diperoleh secara alamiah atau melalui proses pendidikan. ${ }^{4}$ Menurut Budiharto, pengetahuan merupakan ranah kognitif yang mempunyai tingkatan, yaitu: ${ }^{5}$

1. Tahu (know): Seseorang dapat dikatakan tahu ketika dapat mengingat suatu materi yang telah dipelajari; Misalnya, anak dapat menyebutkan manfaat menggosok gigi.

2. Memahami (comprehension): Seseorang dikatakan telah memahami jika ia mampu menjelaskan secara benar tentang objek yang diketahui dan dapat menarik kesimpulan materi tersebut secara benar; Misalnya, anak dapat menjelaskan pentingnya menggosok gigi setiap hari.

3. Aplikasi (application): Aplikasi diartikan sebagai kemampuan untuk menggunakan materi yang telah dipelajari pada situasi atau kondisi sebenarnya; Misalnya, anak akan melakukan gosok gigi setiap hari ketika mereka telah memahami pentingnya menjaga kesehatan gigi.

4. Analisis (analysis): Seseorang dikatakan mencapai tingkat analisis ketika mampu menjabarkan ilmu pengetahuan ke dalam komponen ilmu yang lebih spesifik, tetapi masih dalam struktur yang sama dan berkaitan satu sama lain. Misalnya, anak dapat membedakan, memisahkan, mengelompokkan tindakan yang baik, makanan yang dapat merusak gigi, dsb.

5. Sintesis (synthesis): Sintesis merupakan kemampuan anak untuk menghubungkan bagian-bagian ke dalam suatu bentuk keseluruhan yang baru. Misalnya, anak dapat menyusun, merencanakan, menyesuaikan suatu teori dan rumusan yang telah ada.

6. 6.Evaluasi (evaluation): Evaluasi merupakan kemampuan untuk melakukan penilaian terhadap suatu materi. Misalnya, melihat perbedaan antara anak yang rajin menggosok gigi dengan yang tidak.

Menurut Edwina Kidd tahun 1992, karies merupakan suatu penyakit jaringan keras gigi, yaitu email, dentin, dan sementum yang disebabkan oleh aktivitas suatu jasad renik dalam karbohidrat yang dapat diragikan. ${ }^{3}$ Gejala klinis karies gigi adalah demineralisasi jaringan keras gigi yang kemudian diikuti oleh kerusakan bahan organiknya dan berakibat terjadi invasi bakteri dan kematian pulpa serta 
menyebabkan penyebaran infeksi ke jaringan periapikal yang dapat menyebabkan rasa nyeri. Namun, karena adanya proses remineralisasi, karies gigi pada stadium dini dapat dihentikan. ${ }^{8}$ Karies gigi dapat disebabkan oleh empat faktor berikut: 1) Plak merupakan materi yang bersifat lengket dan menjadi tempat akumulasi mikroorganisme pada permukaan gigi; -9 $^{6}$ 2) Karbohidrat menyediakan substrat untuk pembuatan asam bagi bakteri dan sistesa polisakarida ekstrasel; 3) Kerentanan permukaan gigi menunjukkan area dimana plak lebih mudah melekat dan berakumulasi membentuk proses karies, seperti pit dan fissure gigi; 4) Waktu menunjukkan bahwa proses karies terdiri dari periode pengrusakan dan perbaikan yang terjadi silih berganti. ${ }^{7,10,11}$

\section{BAHAN DAN METODE PENELITIAN}

Penelitian ini merupakan penelitian deskriptif analitik dengan pendekatan cross sectional. Penelitian ini dilakukan di SDN Tumaluntung pada bulan Desember 2014 sampai dengan April 2015. Populasi penelitian ini ialah anak kelas $\mathrm{V}$ yang berjumlah 45 orang. Penelitian ini mengambil seluruh siswa kelas $\mathrm{V}$ dengan kriteria inklusi: bersedia dijadikan sampel, dan bersifat kooperatif selama proses penelitian; sedangkan kriteria eksklusi: memiliki riwayat penyakit sistemik, dan tidak hadir saat penelitian dilaksanakan.

Penelitian ini menggunakan kuesioner, indeks DMF-T dan alat diagnostik. Kuesioner yang digunakan yaitu kuesioner untuk mengukur pengetahuan tentang kesehatan gigi yang sudah digunakan peneliti sebelumnya dan telah divalidasi oleh pakar (dosen pembimbing). Indeks DMF-T adalah indeks yang digunakan pada gigi permanen untuk menunjukkan jumlah gigi yang terkena karies (D), telah dicabut dan diindikasikan pencabutan (M), dan gigi yang telah dirawat $(\mathrm{F}) .^{2,10}$ Alat dan bahan yang digunakan yaitu kaca mulut, sonde, nierbeken, pinset, alkohol 70\%, masker, dan sarung tangan.

Data hasil pengisian kuesioner dimasukkan dalam program Microsoft Excel 2007, kemudian analisis data digunakan program SPSS (Statistical Program for Service Solution) menggunakan uji korelasi Spearman.

\section{HASIL PENELITIAN}

Dalam penelitian ini terdapat 45 siswa yang menjadi sampel penelitian berdasarkan kriteria inklusi dan eksklusi. Berdasarkan Tabel 1 tampak sebagian besar subjek penelitian memiliki tingkat pengetahuan baik mengenai pemeliharaan kesehatan gigi.

Data mengenai tingkat keparahan karies gigi ditunjukkan dalam Tabel 2 . Tampak sebagian besar sampel perempuan memiliki tingkat keparahan karies sangat rendah (18 sampel) sedangkan laki-laki sebagian besar memiliki tingkat keparahan rendah (10 sampel). Tidak ada sampel yang memiliki tingkat keparahan sangat tinggi.

Data mengenai distribusi responden berdasarkan tingkat pengetahuan pemeliharaan kesehatan gigi dan tingkat keparahan karies gigi ditunjukkan dalam Tabel 3. Tampak dari 5 sampel dengan kategori pengetahuan buruk, tidak terdapat sampel dengan tingkat keparahan sangat tinggi, 2 sampel dengan kategori tinggi, satu sampel dengan kategori sedang, satu dengan kategori rendah, dan satu dengan kategori sangat rendah. Sedangkan untuk kategori pengetahuan baik, tidak terdapat sampel dengan kategori keparahan sangat tinggi, 4 sampel dengan kategori sedang, 14 sampelkategori rendah, dan 25 sampel dengan kategori sangat rendah.

Hasil tersebut menunjukkan tidak ada hubungan antara tingkat pengetahuan pemeliharaan kesehatan gigi dengan tingkat keparahan karies berdasarkan interpretasi nilai $\mathrm{r}$ yaitu 0,2 - 0,399 dengan hasil penelitian berdasarkan analisis statistik uji korelasi Spearman dengan nilai r=0,372. 
Lintang, Palendeng, Leman: Hubungan tingkat pengetahuan...

Tabel 1. Distribusi responden berdasarkan Tingkat Pengetahuan Pemeliharaan Kesehatan Gigi

\begin{tabular}{|c|c|c|c|c|c|c|}
\hline \multirow{3}{*}{$\begin{array}{c}\text { Jenis } \\
\text { kelamin }\end{array}$} & \multicolumn{4}{|c|}{ Tingkat pengetahuan } & \multirow[t]{3}{*}{ Total } & \multirow[t]{3}{*}{$\%$} \\
\hline & \multicolumn{2}{|c|}{ Baik } & \multicolumn{2}{|c|}{ Buruk } & & \\
\hline & $\mathrm{n}$ & $\%$ & $\mathrm{n}$ & $\%$ & & \\
\hline Perempuan & 23 & 51,1 & 1 & 2,2 & 24 & 53,3 \\
\hline Laki-laki & 17 & 37,8 & 4 & 8,9 & 21 & 46,7 \\
\hline Total & 40 & 88,9 & 5 & 11,1 & 45 & 100 \\
\hline
\end{tabular}

Tabel 2. Distribusi responden berdasarkan Tingkat Keparahan Karies Gigi

\begin{tabular}{ccccccc}
\hline \multirow{2}{*}{ Jenis kelamin } & \multicolumn{4}{c}{ Tingkat keparahan karies gigi } & Total \\
\cline { 2 - 5 } & $\begin{array}{c}\text { Sangat } \\
\text { tinggi }\end{array}$ & Tinggi & Sedang & Rendah & $\begin{array}{c}\text { Sangat } \\
\text { rendah }\end{array}$ & \\
\hline Perempuan & 0 & 0 & 2 & 4 & 18 & 24 \\
Laki-laki & 0 & 2 & 2 & 10 & 7 & 21 \\
Total & 0 & 2 & 4 & 14 & 25 & 45 \\
\hline
\end{tabular}

Tabel 3. Distribusi responden berdasarkan tingkat pengetahuan pemeliharaan kesehatan gigi dan tingkat keparahan karies gigi

\begin{tabular}{ccccccc}
\hline Pengetahuan & \multicolumn{5}{c}{ Tingkat keparahan karies gigi } & Total \\
\cline { 2 - 5 } & $\begin{array}{c}\text { Sangat } \\
\text { tinggi }\end{array}$ & Tinggi & Sedang & Rendah & $\begin{array}{c}\text { Sangat } \\
\text { rendah }\end{array}$ & \\
\hline Buruk & 0 & 2 & 1 & 1 & 1 & 5 \\
Baik & 0 & 0 & 3 & 13 & 24 & 40 \\
Total & 0 & 2 & 4 & 14 & 25 & 45 \\
\hline \multicolumn{7}{c}{$r=0,372$}
\end{tabular}

\section{BAHASAN}

Berdasarkan hasil penelitian ini, sebagian besar siswa (40) memiliki tingkat pengetahuan baik dan lima siswa memiliki tingkat pengetahuan buruk. Pengetahuan merupakan domain yang sangat penting untuk terbentuknya tindakan seseorang. Pengetahuan siswa sangat penting dalam mendasari terbentuknya prilaku yang mendukung kebersihan gigi dan mulutnya. 11,12 Pengetahuan mengenai kesehatan gigi dan mulut sangat penting untuk terbentuknya tindakan menjaga kebersihan gigi dan mulut. Menjaga kebersihan gigi dan mulut pada usia sekolah merupakan salah satu cara dalam meningkatkan kesehatan pada usia dini. ${ }^{13}$

Penelitian yang dilakukan pada siswa SDN Tumaluntung diperoleh hasil tidak adanya hubungan yang kuat antara tingkat pengetahuan pemeliharaan kesehatan gigi dengan tingkat keparahan karies gigi, karena mengingat pengetahuan bukan merupakan satu-satunya faktor yang mempengaruhi tingkat keparahan karies gigi. Banyak faktor yang dapat menimbulkan karies gigi pada anak, di antaranya adalah faktor dalam mulut yang berhubungan langsung dengan proses terjadinya karies gigi antara lain: struktur gigi, morfologi gigi, susunan gigi-geligi dalam rahang, derajat keasaman saliva, kebersihan mulutyang berhubungan dengan frekuensi dan kebiasaan menggosok gigi, jumlah, dan frekuensi makan makanan yang menyebabkan karies. ${ }^{14,15}$ Selain itu, terdapat faktor luar sebagai faktor predisposisi dan penghambat yang berhubungan tidak langsung dengan terjadinya karies gigi antara lain usia, jenis kelamin, letak geografis, tingkat ekonomi, serta pengetahuan, sikap, dan prilaku 
terhadap pemeliharaan kesehatan gigi.

Responden yang memiliki tingkat pengetahuan buruk dengan tingkat keparahan tinggi terdapat 2 orang, sedangkan untuk tingkat keparahan sedang, rendah dan sangat rendah terdapat masingmasing satu orang. Hal ini membuktikan bahwa, walaupun siswa memiliki pengetahuan yang kurang atau buruk, tidak semua responden memiliki tingkat keparahan tinggi, karena terdapat responden yang memiliki tingkat keparahan rendah dan sangat rendah.

Pada tingkat pengetahuan baik, ditemukan 24 responden dengan tingkat keparahan karies sangat rendah, 13 dengan tingkat keparahan rendah, 3 dengan tingkat keparahan sedang, dan tidak ada responden dengan tingkat keparahan tinggi dan sangat tinggi. Hal ini menunjukkan bahwa meskipun responden paling banyak terdapat pada kategori tingkat keparahan sangat rendah, tetapi ditemukan pula beberapa responden pada tingkat keparahan sedang.

Hasil uji korelasi Spearman menunjukkan bahwa tidak terdapat hubungan antara kedua variabel. Hal ini menunjukkan bahwa tingginya pengetahuan anak mengenai kesehatan gigi belum tentu mempengaruhi kebersihan gigi dan mulut. Cukupnya pengetahuan dan perhatian yang diberikan oleh orang tua dengan mengajari dan mengawasi keseharian anak dalam menjaga kebersihan gigi dan mulutnya dapat mempengaruhi kebersihan gigi dan mulut. Jadi, anak yang memiliki pengetahuan baik harus diimbangi dengan bimbingan orang tua, supaya pengetahuan tersebut dapat diaplikasikan menjadi kebiasaan sehari-hari.

\section{SIMPULAN DAN SARAN}

Berdasarkan hasil penelitian dapat disimpulkan bahwa tidak terdapat hubungan antara tingkat pengetahuan pemeliharaan kesehatan gigi dengan tingkat keparahan karies gigi di SDN Tumaluntung, Kabupaten Minahasa Utara; Sebagian besar siswa memiliki tingkat pengetahuan baik mengenai pemeliharaan kesehatan gigi; Tingkat keparahan karies terbanyak yaitu sangat rendah, sedangkan kategori sangat tinggi tidak ada.

\section{SARAN}

Disarankan orang tua mengajarkan anak sejak dini untuk menjaga kesehatan rongga mulutnya karena akan bedampak ketika anak telah dewasa nanti,

Perlu untuk dilakukan penelitian lebih lanjut tentang faktor-faktor yang memengaruhi tingkat keparahan karies gigi, karena penelitian ini hanya membahas satu faktor yaitu pengetahuan anak.

\section{DAFTAR PUSTAKA}

1. Susanto A. Kesehatan gigi dan mulut. Jakarta: Sunda Kelapa Pustaka, 2007.

2. Astiana WI. Hubungan sikap dan pengetahuan masyarakat tentang pencabutan gigi [Skripsi]. Makassar: Fakultas Kedokteran Gigi Universitas Hasanudin; 2007.

3. Riskesdas [online] 2013 [cited 2014 November 11]. Available from URL: http//www.litbang.depkes.go.id/simna s4/day.2/gigi.pdf.

4. Bakhtiar A. Filsafat ilmu. Edisi revisi II. Jakarta: PT Raja Grafindo Persada, 2004; p. 85-122.

5. Budiharto J. editor. Pengantar ilmu perilaku kesehatan pendidikan kesehatan gigi. Jakarta: EGC, 2010; p. $18-20$.

6. Gurenlian JR. The role of dental plaque biofilm in oral health. Journal of Dental Hygiene. 2007;81(15).

7. Kidd EAM, Joyston-Bechal S. Dasar-dasar karies. Alih Bahasa: Narlan S. Jakarta: EGC, 1992; p. 2-9.

8. Cvetkovic A, Ivanovic $M$. The role of streptococcus mutan group and salivary immunoglobulin in etiology of early childhood caries. Serbian dental; 2006. p.53

9. Pintauli S, Hamada T. Menuju gigi dan mulut sehat. Medan: USU Press, 2005; p. 4-24.

10.Roberson TM, Heyman HD, Swift EJ, editors. Sturdevants's art and science operative dentistry $4^{\text {th }}$ ed. North Carolina: Mosby, 2002; p. 69-99.

11.Ignatia PS, Trining W, Ranny R. Perbedaan tingkat pengetahuan 
kesehatan gigi dan mulut pada siswa sekolah dasar di kota dan di desa; 2013: 1-2

12.Sariningrum E, Indrawanti. Hubungan tingkat pendidikan, sikap, dan pengetahuan orang tua tentang kebersihan gigi dan mulut pada anak balita 3-5 tahun dengan tingkat kejadian karies di Paud Jatipurno. Berita Ilmu Keperawatan ISSN 2009; 2 no 3 (1979-1997): 119-124.

13.Herijulianti E, Indriani TS, Artini S. Pendidikan kesehatan gigi. Jakarta: Buku Kedokteran EGC, 2001; p. 98.
14.Dewanti. Hubungan tingkat pengetahuan tentang kesehatan gigi dengan perilaku perawatan gigi pada anak usia sekolah di SDN Pondok Cina 4 Depok [Skripsi]. Depok: Fakultas Ilmu Keperawatan Program Sarjana Reguler Depok; 2012.

15.Barus D. Hubungan kebiasaan makan dan pemeliharaan kesehatan gigi dan karies gigi pada anak SD 060935 di jalan Pintu Air II Simpang Gudang kota Medan tahun 2008. Medan: USU Press, 2009; p. 57-61. 